\title{
Feeding Treatment Based on Palm Oil by Product and Supplementation to Support Reproduction Performance of Bull
}

\author{
Dian Ratnawati and Aryogi \\ Beef Cattle Research Institute, Jln. Pahlawan No 2 Grati, Pasuruan \\ Corresponding author email: dian_sapo@yahoo.co.id
}

\begin{abstract}
Palm oil waste (by product) can be used as a potential feed for livestock. Nevertheless, the study research of the effect of Palm oil waste (by product) as a feed to the bull performance was limited. The purpose of this research is to get technology to improve semen quality through improving protein of feed based on palm oil waste (by products). This research was conducted in PTPN 6 Jambi and used 30 bulls that separated into 3 treatments, treatment I (feed protein 12\% and supplementation), treatment II (feed protein $12 \%$ ) and treatment III (existing feed, feed protein 10\%). Parameter were measured i.e sperm quality (sperm motility, mass movement, sperm concentration, percentage of live sperm, sperm abnormalities), feed consumption, body condition score (BCS) and average daily gain (ADG). Design of this research was completely randomized design. Data was analyzed use ANOVA. The result showed that there is no significantly different on semen quality between treatments. Semen quality of three treatments were appropriate to standard of quality semen of bull (sperm abnormality $<20 \%$, sperm motility $>50 \%$ and sperm concentration $>500$ million/ml). It can be concluded that dietary protein level of $10 \%$ and $12 \%$ based on palm oil by product can maintain semen quality of bulls. Palm oil by product can be a potential feed to increase productivity and reproduction performance.
\end{abstract}

Key words: semen quality, bull, palm oil by product

Abstrak. Limbah sawit dapat digunakan sebagai sumber pakan ternak yang potensial. Namun demikian, kajian tentang dampak limbah sawit terhadap performans pejantan masih terbatas. Tujuan penelitian ini adalah untuk memperoleh teknologi yang dapat digunakan untuk meningkatkan kualitas semen dengan meningkatkan kandungan protein pada pakan basal yang menggunakan limbah sawit. Penelitian dilakukan di PTPN 6 Jambi menggunakan 30 pejantan yang terbagi dalam 3 perlakuan, perlakuan I (protein pakan 12\% ditambah suplementasi), perlakuan II (protein pakan 12\%), dan perlakuan III (pakan standar, protein pakan 10\%). Parameter yang diukur yakni kualitas sperma (motilitas, pergerakan massa, konsentrasi, persentase sperma hidup, dan abnormalitas sperma), konsumsi pakan, body condition score (BCS), dan pertambahan bobot badan. Penelitian menggunakan rancangan acak lengkap. Data dianalisis menggunakan ANOVA. Hasil penelitian menunjukkan bahwa tidak terdapat perbedaan kualitas semen antar ketiga perlakuan tersebut. Kualitas semen pada ketiga perlakukan menunjukkan kualitas semen standar (abnormalitas $<20 \%$, motilitas $>50 \%$ dan konsentrasi $>500 \mathrm{juta} / \mathrm{ml}$ ). Dapat disimpulkan bahwa protein pakan pada level $10 \%$ dan $12 \%$ berbasis limbah sawit dapat mempertahankan kualitas semen. Limbah sawit merupakan pakan potensial yang dapat digunakan untuk meningkatkan performans produksi dan reproduksi.

Kata kunci: kualitas semen, pejantan, limbah sawit

\section{Introduction}

Bull should have a high fertility to supporting productivity of cow. Fertility of bull can be defined through breeding soundness evaluation (BSE) which consider many factors such as semen quality (motility and morphology sperm) and scrotal circumfence (Bruner et al., 1995) . Basic classification on BSE depended on breed (Godfrey and Dodson, 2005), body condition score (excessive or poor), physically condition (healthy, stress) of bull (Barth and Waldner, 2002).

Feed has a high influence to the biological potential of beef cattle, including production and reproduction aspects. Feeding needs to consider the nutritional needs according to the physiological status of livestock. Palm oil has various advantages such as a food, non-food industry, and animal feed. Previously research 
showed that dietary protein level $12-18 \%$ capable to produce average daily gain (ADG) of bull 0.78 to $0.90 \mathrm{~kg}$ (Umiyasih et al., 2012). The needs of vitamins and minerals may also to be a consideration to support productivity of livestock, such as selenium and vitamin E. Vitamin has a great influence to body metabolism, which is vitamin E play an important role to preventing free radicals.

The purpose of this study was to obtain technology to improve the quality of semen through improving dietary protein-based on palm oil by product.

\section{Materials and Method}

This research was conducted in PTPN 6 (Muaro Jambi, Jambi Province) for 16 weeks. The material used 30 bulls, consisted of two breeds (PO and Bali). There were three treatments of feed : treatment I, protein level $12 \%$ with supplementation (vitamin E $1000 \mathrm{mg}$ and selenium $5 \mathrm{mg} /$ head); treatment II, protein level $12 \%$ and treatment III, existing feed with protein level $10 \%$. Supplementation was done every 2 weeks. Composition of feed has a big part of palm oil by product, there were: palm fronds, palm kernel cake etc.

Collecting semen was done before treatment and every 4 weeks during the research. Parameters were measured include: sperm quality (sperm motility, mass movement, sperm concentration, percentage of live sperm, sperm abnormalities), feed consumption, body condition score (BCS) and average daily gain (ADG). Design of this research were completely randomized design. Data was analyzed by ANOVA.

Table 1.Treatment and material of research.

\begin{tabular}{lcc}
\hline Treatment & PO bull & Bali bull \\
\hline $\begin{array}{l}\text { Protein } \\
\text { 12\%+supplementation }\end{array}$ & 5 heads & 5 heads \\
Protein $12 \%$ & 5 heads & 5 heads \\
\begin{tabular}{lll} 
Existing feed (protein & 5 heads & 5heads \\
$10 \%)$ & & \\
\hline
\end{tabular}
\end{tabular}

\section{Results and Discussion}

Monitoring of body performance of bulls was conducted during this research. According to the table 1 , initial weight of PO and Bali bull ranges between $283 \mathrm{~kg}$ and $242 \mathrm{~kg}$ with initial body condition score 2.8 to 2.9 and from 2.9 to 3.0. Tooth status of the bulls were used 10-13. Feeding treatment was conducted for 16 weeks showed ADG 0.3-0.5 kg / day (PO bull) and 0.3 $\mathrm{kg} /$ day (Bali bull). Final body condition score showed an increase i.e. 3.1-3.3 (PO bull) and 2.9 to 3.0 (Bali bull).

Table 2.Body performance of bulls

\begin{tabular}{|c|c|c|c|c|c|c|}
\hline \multirow{3}{*}{ Parameter } & \multicolumn{3}{|c|}{ PO bull } & \multicolumn{3}{|c|}{ Bali bull } \\
\hline & \multicolumn{3}{|c|}{ Treatment } & \multicolumn{3}{|c|}{ Treatment } \\
\hline & I & II & III & 1 & II & III \\
\hline $\begin{array}{l}\text { Initial body } \\
\text { weight (kg) }\end{array}$ & $283.0 \pm 32.9$ & $283.4 \pm 35.6$ & $283.8 \pm 36.7$ & $242.0 \pm 20.1$ & $242.2 \pm 26.3$ & $242.0 \pm 13.2$ \\
\hline $\begin{array}{l}\text { Initial BCS } \\
(1-5)\end{array}$ & $2.8 \pm 0.3$ & $2.9 \pm 0.1$ & $2.8 \pm 0.2$ & $3.0 \pm 0.2$ & $2.9 \pm 0.2$ & $3.0 \pm 0.3$ \\
\hline $\begin{array}{l}\text { Final body } \\
\text { weight (kg) }\end{array}$ & $324.4 \pm 42.2$ & $342.8 \pm 53.6$ & $340.4 \pm 44.6$ & $277.0 \pm 33.5$ & $274.4 \pm 22.3$ & $278.2 \pm 24.1$ \\
\hline $\begin{array}{l}\text { Final BCS } \\
(1-5)\end{array}$ & $3.1 \pm 0.3$ & $3.3 \pm 0.4$ & $3.2 \pm 0.2$ & $2.9 \pm 0.1$ & $3.0 \pm 0$ & $3.0 \pm 0$ \\
\hline ADG (kg/day) & $0.3 \pm 0.3$ & $0.5 \pm 0.3$ & $0.5 \pm 0.2$ & $0.3 \pm 0.2$ & $0.3 \pm 0.1$ & $0.3 \pm 0.1$ \\
\hline
\end{tabular}




\section{Collecting semen}

At the beginning of the study, it is known that big part of bulls cannot be collected and analyzed. However, after the treatment of the feed showed different results. This following table was a progress bulls in collecting semen during research and its semen quality.

Table 3 showed before treatment, only one bali bull can produce semen. Nevertheless, the semen quality was poor, it was shown with sperm motility $5 \%$, concentration of 420 million/ml, and death sperm percentage $50 \%$. Hafez (2000) stated that standard quality semen should have sperm concentration 800 1000 million / $\mathrm{ml}$ and death sperm percentage $<20 \%$. At treatment III, there were four bali bulls successfully collected and analyzed the semen quality. It was shown motility $>60 \%$ and sperm concentration $>1,000$ million / ml. Bull with this semen quality deserve to be a semen sources for natural mating or artificial insemination (Al).

At the semen collecting II (4 weeks of treatment cement) showed an increasing number of bulls that can be collected and analyzed (Table 4). Semen quality (Bali and PO bull) have been increased, ie: motility $>65 \%$, sperm concentration $>1000$ million $/ \mathrm{ml}$ and sperm abnormalities $<20 \%$. Nevertheless, bali bulls of treatment I showed low quality semen ( $45 \%$ motility and sperm concentration of 770 million / $\mathrm{ml}$ ) and PO bulls cannot be collected.

Table 3. Semen quality at semen collecting I

\begin{tabular}{|c|c|c|c|c|c|c|}
\hline \multirow{3}{*}{$\begin{array}{c}\text { Parameter of semen } \\
\text { quality }\end{array}$} & \multicolumn{3}{|c|}{ PO bull } & \multicolumn{3}{|c|}{ Bali bull } \\
\hline & \multicolumn{3}{|c|}{ Treatment } & \multicolumn{3}{|c|}{ Treatment } \\
\hline & 1 & II & III & 1 & II & III \\
\hline Sperm motility (\%) & - & - & - & - & 5.0 & $63.8 \pm 39.2$ \\
\hline Mass movement (1-4) & - & - & - & - & 1.0 & $2.5 \pm 1.0$ \\
\hline $\begin{array}{l}\text { Sperm concentration } \\
\text { (million/ml) }\end{array}$ & - & - & - & - & 420.0 & $1165.0 \pm 553.4$ \\
\hline Live sperm (\%) & - & - & - & - & 32.0 & $72.0 \pm 33.2$ \\
\hline Dead sperm (\%) & - & - & - & - & 50.0 & $30.3 \pm 35.3$ \\
\hline Abnormality (\%) & - & - & - & - & 18.0 & $1.0 \pm 0.0$ \\
\hline
\end{tabular}

Table 4. Semen quality at semen collecting II

\begin{tabular}{lcccccc}
\hline \multirow{2}{*}{$\begin{array}{c}\text { Parameter of semen } \\
\text { quality }\end{array}$} & \multicolumn{3}{c}{ PO bull } & \multicolumn{3}{c}{ Bali bull } \\
\cline { 2 - 6 } & \multicolumn{2}{c}{ Treatment } & \multicolumn{3}{c}{ Treatment } \\
\hline Sperm motility (\%) & $67.5 \pm 24.7$ & $83.3 \pm 2.9$ & - & $45.0 \pm 42.4$ & $66.7 \pm 27.5$ & $80.0 \pm 5.0$ \\
Mass movement (1-4) & $2.0 \pm 1.4$ & $2.7 \pm 0.6$ & - & 2.0 & $2.5 \pm 0.7$ & $2.0 \pm 1.0$ \\
Sperm concentration & $1070 \pm 579.8$ & 1286.7 & - & $770.0 \pm$ & $735.0 \pm$ & $1220.0 \pm$ \\
(million/ml) & & \pm 287.3 & & 268.7 & 606.3 & 370.4 \\
Live sperm (\%) & $77.0 \pm 2.8$ & $83.0 \pm 8.5$ & - & $41.0 \pm 33.9$ & $61.7 \pm 24.1$ & $82.0 \pm 8.0$ \\
Deadth sperm (\%) & $22.5 \pm 3.5$ & $14.3 \pm 8.2$ & - & $57.5 \pm 33.2$ & $53.0 \pm 36.6$ & $18.3 \pm$ \\
Abnormality (\%) & $1.0 \pm 0.0$ & $0.3 \pm 0.5$ & - & $1.5 \pm 0.7$ & $0.8 \pm 1.0$ & $1.3 \pm 1.5$ \\
\hline
\end{tabular}


At the semen collecting III (after 8 weeks of treatment of feed), the number of bulls that can be collected show improvement (Table 5). At the collecting III, there were increasing semen quality of PO and Bali bull. Sperm concentration in average $>1000$ million / $\mathrm{ml}$ in Bali bulls (treatment I, II and III) and PO bulls (treatment II and III). Sperm motility of bali and PO bull in range $72-81 \%$ and $60-71 \%$. Live sperm of bali and $\mathrm{PO}$ bull in range $75-79 \%$ and $74-84 \%$. Sperm abnormalities in normal range of $<20 \%$.

The different result showed at collecting IV (12 weeks after treatment Feed). It was shown in Table 6. Table 6 showed that there were decreasing of semen quality, especially in treatment III of PO bull. Sperm motility decreased, i.e. $45-60 \%$, as well as sperm concentration $<1000$ million/ml. Sperm motility of bali bulls showed relatively stable, i.e. 62-
$82 \%$ and sperm concentration values $>1000$ million/ml. There was a decline on live sperm percentage i.e. $59-76 \%$.

\section{Semen quality}

At the beginning of research, only a few number of bulls that can be collected. There an increasing of bulls that can be collected as long as this research. This was caused by the habit of interaction between males and females. Bulls have not collected yet before being used as material research. Interaction between bull and cow can stimulate libido. The mechanism of stimulation came from stimulus through visual, olfactory and tactile. Stimulation delivered to the central nervous system, through spinal cord to corpus cavernous. This erectile tissue, stimulus resulted neurotransmitter so that an erection of penis.

Table 5. Semen quality at semen collecting III

\begin{tabular}{|c|c|c|c|c|c|c|}
\hline \multirow{3}{*}{$\begin{array}{c}\text { Parameter of semen } \\
\text { quality }\end{array}$} & \multicolumn{3}{|c|}{ PO bull } & \multicolumn{3}{|c|}{ Bali bull } \\
\hline & \multicolumn{3}{|c|}{ Treatment } & \multicolumn{3}{|c|}{ Treatment } \\
\hline & I & II & III & I & II & III \\
\hline Sperm motility (\%) & $70.0 \pm 0.0$ & $71.7 \pm 11.5$ & $\begin{array}{r}60.0 \\
\pm 28.3\end{array}$ & $72.5 \pm 17.7$ & $81.3 \pm 7.5$ & $70.0 \pm 15.0$ \\
\hline Mass movement (1-4) & 1.0 & $1.7 \pm 1.2$ & $1.5 \pm 0.7$ & $2.0 \pm 1.4$ & $2.8 \pm 0.5$ & $2.0 \pm 1.0$ \\
\hline $\begin{array}{l}\text { Sperm concentration } \\
\text { (million/ml) }\end{array}$ & $\begin{array}{c}650.0 \pm \\
381.8\end{array}$ & $\begin{array}{c}1900.0 \pm \\
910.2\end{array}$ & $\begin{array}{c}1200.0 \pm \\
876.8\end{array}$ & $\begin{array}{c}1170.0 \pm \\
1173.8\end{array}$ & $\begin{array}{c}2165.0 \pm \\
738.4\end{array}$ & $1660.0 \pm 778.7$ \\
\hline Live sperm (\%) & $79.5 \pm 0.7$ & $75.3 \pm 10.7$ & $77.5 \pm 3.5$ & $84.0 \pm 5.7$ & $86.8 \pm 2.4$ & $74.7 \pm 12.5$ \\
\hline Dead sperm (\%) & $18.5 \pm 0.7$ & $20.3 \pm 9.0$ & $16.0 \pm 7.0$ & $14.0 \pm 7.0$ & $11.0 \pm 2.4$ & $19.3 \pm 10.3$ \\
\hline Abnormality (\%) & $2.0 \pm 0.0$ & $4.3 \pm 2.1$ & $6.5 \pm 3.5$ & $2.0 \pm 1.4$ & $2.3 \pm 1.5$ & $6.0 \pm 3.6$ \\
\hline
\end{tabular}

Table 6. Semen quality at semen collecting IV

\begin{tabular}{|c|c|c|c|c|c|c|}
\hline \multirow{3}{*}{$\begin{array}{c}\text { Parameter of semen } \\
\text { quality }\end{array}$} & \multicolumn{3}{|c|}{ PO bull } & \multicolumn{3}{|c|}{ Bali bull } \\
\hline & \multicolumn{3}{|c|}{ Treatment } & \multicolumn{3}{|c|}{ Treatment } \\
\hline & 1 & II & III & 1 & II & III \\
\hline Sperm motility (\%) & $80.0 \pm 40.2$ & $50.0 \pm 36.1$ & 45.0 & $82.5 \pm 3.5$ & $82.0 \pm 2.7$ & $62.5 \pm 35.0$ \\
\hline Mass movement (1-4) & $2.3 \pm 0.6$ & $2.0 \pm 1.4$ & 1.0 & $3.0 \pm 0.0$ & $2.8 \pm 0.4$ & $2.7 \pm 0.6$ \\
\hline Sperm concentration & $925.0 \pm$ & 920.0 & $120, .0$ & 1900.0 & 1416.0 & $1210.0 \pm$ \\
\hline (million/ml) & 402.1 & \pm 1271.1 & & \pm 424.3 & \pm 480.3 & 800.1 \\
\hline Live sperm (\%) & $49.5 \pm 38.6$ & $34.7 \pm 37.4$ & $68, .0$ & $76.0 \pm 8.5^{\mathrm{a}}$ & $70.6 \pm 2.8^{a}$ & $59.0 \pm 10.2^{b}$ \\
\hline Dead sperm (\%) & $50.3 \pm 38.5$ & $64.0 \pm 37.6$ & 29.0 & $24.0 \pm 8.5$ & $28.8 \pm 2.8$ & $40.0 \pm 10.5$ \\
\hline Abnormality (\%) & $0.3 \pm 0.5$ & $1.3 \pm 1.5$ & 3.0 & $0.5 \pm 0.7$ & $0.6 \pm 0.5$ & $1.0 \pm 0.8$ \\
\hline
\end{tabular}


Semen quality varies in each semen collecting. According to Sarastina et al. (2006) and Chenoweth et al. (1996) stated that there are many factors affecting to the quality and quantity of semen, such as: body weight, age, season, genetic, frequency of collecting sperm, breed, temperature and feed. At the beginning of research, bulls have a uniform character including age, body weight, reproductive status and environment. Variations that occur within individual was very large so that the semen quality different every collecting. The data range was high so that there was no significantly different by statistical analysis. Results showed that there were not significantly differences of semen quality in 3 treatments of feed.

Mostly, semen quality can reach requirement of bull standard. The percentage of normal and abnormal sperm have an important role in this case. Abnormality $<20 \%$ showed that bull has a good performance (Ax et al., 2008; Purwantara et al., 2010). Normality sperm should be reached $70 \%$ (Menon et al., 2011) so that bull has a good fertility. Wang et al. (2015) stated that mostly normality sperm $70 \%$ showed motility $60 \%$. Whereas, scoring motility is very subjective and affected by many factors i.e. collection method, time, temperature, contamination and concentration.

\section{Feed formulation and consumption}

The existing feed in PTPN was mixed feed, consisting of palm fronds, palm kernel cake, rice bran and cassava with total protein ingredient $10 \%$. Feed formulation was done to reach level protein of $12 \%$ by mixing the feed PTPN 6 with other feed ingredients, i.e. rice bran and palm kernel cake (Table 7).

Feed formulation based on the results of proximate analysis of feed materials available on site. Proximate analysis was conducted in the laboratory of nutrition and feed (Beef Cattle Research Institute, Pasuruan).

Feed consumption of bulls monitored by weighing offered and refusal feed of each individual bull for 3 days per month. Consumption data of dry matter and crude protein in PO and Bali bull at treatment I, II and III are shown in Table 9.

Dry matter intake of PO bull significantly different at treatment III to I, and not different with treatment II. Consumption of crude protein not significantly difference between treatments. Meanwhile, dry matter intake in treatment II and III of bali bull significantly different. There was no significantly difference in consumption of crude protein per treatment. The low of consumption in treatment I and II in PO and Bali bull caused by less balance of crude fat i.e. $>6 \%$ which is can interfere with rumen microbes. At treatment III, crude fat was $<6 \%$ so that the consumption becomes higher.

Table 7.Feed formulation (protein $10 \%$ and $12 \%$ ) based on palm oil waste.

\begin{tabular}{|c|c|c|c|}
\hline \multirow{2}{*}{ No } & \multirow{2}{*}{ Feed components } & \multicolumn{2}{|c|}{ Feed formulation (\% dry matter) } \\
\hline & & Protein $10 \%$ & Protein $12 \%$ \\
\hline 1 & PTPN 6 concentrate & 100 & 38 \\
\hline 2 & Rice bran & 0 & 38 \\
\hline 3 & Palm kernel cake & 0 & 24 \\
\hline
\end{tabular}

Table 8.Proximate analysis of feed

\begin{tabular}{lccccc}
\hline \multicolumn{1}{c}{ Feed components } & Dry matter & Crude Protein & Crude Fiber & Crude fat & TDN \\
\hline PTPN 6 concentrate & 55.092 & 10.32 & 30.12 & 4.19 & 60.594 \\
Rice bran & 55.092 & 11.77 & 15.96 & 5.87 & 72.296 \\
Palm kernel cake & 94.008 & 12.31 & 18.88 & 12.8 & 66.392 \\
\hline
\end{tabular}

(Sources: Nutrition and Feed Laboratory of BCRI) 
Table 9.Feed consumption of bull

\begin{tabular}{ccccccc}
\hline \multirow{2}{*}{$\begin{array}{c}\text { Feed } \\
\text { consumption }\end{array}$} & \multicolumn{3}{c}{ PO bull } & \multicolumn{3}{c}{ Bali bull } \\
\cline { 2 - 7 } & \multicolumn{3}{c}{ Treatment } & \multicolumn{3}{c}{ Treatment } \\
\cline { 2 - 7 } & \multicolumn{1}{c}{ II } & III & I & II & III \\
\hline $\mathrm{DM}(\mathrm{kg} /$ day) & $4.03 \pm 0.87^{\mathrm{a}}$ & $4.60 \pm 0.74^{\mathrm{ab}}$ & $5.33 \pm 0.58^{\mathrm{b}}$ & $3.51 \pm 0.52^{\mathrm{ab}}$ & $3.19 \pm 0.54^{\mathrm{a}}$ & $3, .93 \pm 0.34^{\mathrm{b}}$ \\
$\mathrm{CP}(\mathrm{kg} / \mathrm{day})^{*}$ & $0.48 \pm 0.11$ & $0.55 \pm 0.09$ & $0.55 \pm 0.06$ & $0.42 \pm 0.06$ & $0.38 \pm 0.06$ & $0.41 \pm 0.04$ \\
\hline
\end{tabular}

\section{Feed and reproduction}

Feed has a great effect to the reproduction performanceof bull. Feed with optimal nutritional composition which strongly supports to daily weight gain. Body weight and time of puberty, affected by energy of feed consumed. Poor nutrition, especially energy will inhibit sexual development and puberty (Iskandar, 2011). The decline of semen quality may occur due to lack of feed, produce low level of gonadotrophin. It is also affect to spermatogenesis and reproduction performance of steers. Feed restriction causes permanent damage to gonadal tissues.

In some conditions, high level of energy not always give a good effect on reproduction. Semen quality and sperm cells daily production could decrease if feed has a high level of energy (Ratnawati and Anggraeny, 2013). Excessive feeding on young male calves effect on fertility due to accumulation of fat in scrotum and area of plexus pampiniformis that interfere with testicular thermoregulation. High energy level led to an increase of body weight, height and diameter of the scrotum, but it will not affect to puberty or first mating time.

Poor of reproductive due to low feed adequacy can be improved by refeeding (improvement of feed). It needs Feed with optimum energy levels to support growth and efficiency. The synthesis and secretion of reproductive hormones by the glands endocrine influenced by the level of feed provided. Better quality and quantity of feed given to the bull, cause hormone synthesis will be faster.

The mechanism of the effect of nutrition to reproduction, through mechanism of hypothalamus-pituitary axis. Poor nutrition can reduce signal strength of the hypothalamus to secrete GnRH. This hormone gives affect to the anterior pituitary gland's to secrete LH. Low levels of $\mathrm{LH}$ in blood affects to the growth of reproductive organs in cattle. Inhibition of growth caused by nutrients, LH secretion was reduced by a central mechanism by controlling the release of GnRH. Previous result showed that glucose, amino acid and energy level affect to decrease of $\mathrm{LH}$ and FSH level. Low intake of protein also affect to decrease of $\mathrm{LH}$ levels that can delay of puberty in bulls.

Vitamin and mineral have an important role to determine time of puberty of bull. The mechanism is through the influence of the reproductive organs function bulls. Some minerals that have affect to the bulls reproductive i.e. manganese, selenium, copper, zinc, chromium, molybdenum, iron and phosphorus (Dep et al, 2014). Vitamin A and beta carotene contained in forages has an important role as well.

\section{Vitamin E and Selenium}

Giving vitamin E (1000 mg) and selenium (5 $\mathrm{mg}$ ) every 2 weeks on diet (protein 12\%) did not increase semen quality. The function of vitamin $E$ and selenium is an antioxidant to minimize cell damaged. The byproduct of palm oil waste indicated consist of free radicals that can affect the damage of cells, including sperm cells. The high free radical was characterized by high ROS (reactive oxidative species) which can cause damage to the sperm membrane and its function. Damaged cell membranes can affect to the metabolic rate of sperm cells that affect to the motility of spermatozoa. The effect of free radicals can be reduced by antioxidants (Rizal and Herdis, 2010). 
Vitamin $E$ or alpha-tocopherol is an antioxidant compound that serves to capture free radicals by providing the hydrogen atom on peroxyl radical (Alawiyah and Hartono, 2006; Wardly and Jeffrey, 2007; Romadhoni et al, 2014). Alpha-tocopherol is a fat-soluble antioxidant that protects PUFA, components of cells and cell membranes from free radicals (Fitriani, 2013).) Alpha-tocopherol has a effect to increase metabolism in the testicular tissue and better spermatogenesis to produce a normal morphology of spermatozoa. Eskenazi et al (2005); Comhaire et al (2000) and Geva et al (1996) stated that supplementation of alpha tocopherole can increase fertilization rate through reducing lipid peroksidation and oxidative damage.

\section{Conclusions}

Dietary protein level of $10 \%$ and $12 \%$ based on palm oil by product can maintain semen quality of bulls. Palm oil by product can be a potential feed to increase productivity and reproduction performance.

\section{Acknowledgement}

Our gratitude goes to PTPN 6 (Jambi) and team for the cooperation during research activities, providing site and bulls as a research material.

\section{References}

Alawiyah D and M Hartono. 2006. The Effect of Vitamin E in Egg Yolk Citrate Extender on the Frozen Semen Quality of "Boer" Goat. J. Indon. Trop. Anim. Agric. 31 [1] March 2006. Lampung University. Bandar Lampung.

Arifiantini RI, B Purwantara and M Riyadhi. 2012. Occurrence of Sperm Abnormality of Beef Cattle at Several Artificial Insemination Centers in Indonesia. Animal Production 12 (1):44-49.

Ax RL, MR Dally, BA Didion, RW Lenz, CC Love, DD Varner, B Hafez and ME Bellin. 2008. Semen Evaluation. Reproductive in Farm Animals. 8th Edition. Edited by Hafez and Hafez.Lea and Febiger. p. 365-375.
Barth $A D$ and $\mathrm{CL}$ Waldner. 2002. Factors affecting breeding soundness classification of beef bulls examined at the Western College of Veterinary Medicine. Can Vet J. 2002 Apr; 43(4): 274-284.

Bellows DS, SL Ott and RA Bellows. 2002. Review: Cost of reproductive disease and conditions in cattle. Prof. Anim. Sci. 18:26-32.

Bruner KA, RL McGraw, MD Whitacre and SD Van Camp. 1995. Breeding Soundness Examination of 1.952 Yearling Beef Bulls in North Carolina. Theriogenology 44: 129-145.

Chenoweth PJ, CC Chase Jr, M-J D Thatcher, CJ Wilcox and RE Larsen. 1996. Breed and other effects on reproductive traits and breeding soundness categorization in young beef bulls in Florida. Theriogenology 46 (7): 1159-1170. Abstract.

Comhaire FH, Christophe AB, Zalata AA, Dhooge WS, Mahmoud AM and Depuydt CE. 2000. The effects of combined conventional treatment, oral antioxidants and essential fatty acids on sperm biology in subfertile men. Prostaglandins Leukot Essent Fatty Acids 63,159-165.

Dep R, S Chakraborty, Mahima, AK Verma, R Tiwari and K Dhama. 2014. Nutrigenomics and Its Role in Male Puberty of Cattle: A Mini Review. Pakistan Journal of Biological Sciences 17 (3): 329-334.

Eskenazi B, SA Kidd, AR Marks, E Sloter, G Block and AJ Wyrobek. 2005. Antioxidant intake is associated with semen quality in healthy men. Human Reproduction Vol.20, No.4: 1006-1012.

Fitriani. 2013. The effect of alpha tocopherol to semen quality of goose stored in cold temperature. Journal of animal husbandry science 23 (2): 36 - 41. Husbandry Faculty, UB, http://jiip.ub.ac.id/.

Geva E, B Bartoov, N Zabludovsky, JB Lessing, L Lerner-Geva and A Amit. 1996. The effect of antioxidant treatment on human spermatozoa and fertilization rate in an in vitro fertilization program. Fertil Steril 66,430-434.

Godfrey RW and RE Dodson. 2005. Breeding soundness evaluations of Senepol bulls in the US Virgin Islands. Theriogenology 63: 831-840.

Hafez ESE. 2000. Semen Evaluation In Reproduction In Farm Animals. 7th Edition. Lippincott Wiliams and Wilkins. Maryland, USA.

Iskandar. 2011. Reproduction performance of PO cattle in low land and high land of Jambi Province. Scientific journal of animal husbandry.Vol. XIV. No.1. Faculty of Husbandry, Jambi University.

Mathius IW. 2008. Development of beef cattle based palm oil industry. Development of Agricultural Innovation I (2) 2008 : 206-224. 
Menon AG, HW Barkema, R Wilde, JP Kastelic, and JC Thundathil. 2011. Associations between sperm abnormalities, breed, age, and scrotal circumference in beef bulls. Can J Vet Res. 2011 Oct; 75(4): 241-247.

Parkinson TJ, JJ Vermunt and J Malmo. 2010. Disease of Cattle in Australia. Published by The New Zealand Veterinary Association Foundation for Continuing Education. Australia.

Purwantara B, RI Arifiantini and M Riyadhi. 2010. Sperm Morphological Assesments of Frisien Holland Bull semen collected from three Artificial Insemination Centers in Indonesia. J. Indonesian Trop. Anim. Agric 32 (5).

Ratnawati D and YN Anggraeny. 2013. Puberty and semen quality of PO steers with feeding based on cassava. Proceeding of national conference on Livestock Production and Veterinary Technology. Indonesian Center for Animal Research and Development (ICARD). Bogor.

Rizal and Herdis. 2010. The role of antioxidants in Improving Quality of Frozen Semen. Wartazoa Vol. 20 No. 3, 2010.

Romadhoni I, A Rachmawati and Suyadi. 2014. Semen quality of madura bull after diluting with tris aminomethane egg yolk supplemented with alpha tocopherol at room temperature storage. Journal of animal husbandry science 24 (1): 3944. Brawijaya University. Malang.

Sarastina, T Susilawati and G Ciptadi. 2006. Analysist Parameter of Sperm Bull Motility by using Computer Assisted Semen Analysis (CASA). J. Ternak Tropika 6 (2): 1-12.

Umiyasih U, TA Sulistya dan R Antari. 2012. The effect of level of usage Palm Kernel Cake and Copra Meal on Concentrate Based on Cassava by Product to average daily gain of PO steer. Proceeding of national conference on Livestock Production and Veterinary Technology. Indonesian Center for Animal Research and Development (ICARD). Bogor.

Wang Z, MG Colazo, J A Basarab, L A Goonewardene, DJ Ambrose, E Marques, G Plastow, SP Miller and SS Moore. 2015. Impact of selection for residual feed intake on breeding soundness and reproductive performance of bulls on pasturebased multisire mating. JAS Vol. 90 No. 9, p. 2963-2969. 